\section{BANGLADESH People's Republic of Bangladesh}

Area: 144,020 sq. $\mathrm{km}$

Population: $92,000,000$

Capital: Dacca [Dhaka]

Head of State: Lieut.-Gen. Hossain Mohammad Ershad (President)

Minister of Home Affairs: Maj.-Gen. V. M. K. Choudhury

Bangladesh comprises 4 divisions, under divisional commanders, subdivided into 20 districts, as follows:

Chittagong division: Chittagong; Chittagong Hill Tracts; Comilla; Noakhali; Sylhet.

Dacca division: Dacca; Faridpur; Jamalpur; Mymensingh; Tangail.

Khulna division: Barisal; Jessore; Khulna; Kushtia; Patuakhali.

Rajshahi division: Bogra; Dinajpur; Pabna; Rajshahi; Rangpur.

\section{ORGANIZATION}

The Bangladesh Police is organized by divisions and districts and headed by an Inspector General of Police, who reports to the Ministry of Home Affairs. Each district headquarters is under a police superintendent. The inherited administrative structure is retained (see PAKISTAN for details). The force has paramilitary capability and includes an efficient riot control element. There are at present 486 active police stations. The Chittagong Metropolitan Police and the Dacca Metropolitan Police have separate administrations and are headed by Police Commissioners.
The Anti-Corruption Department, administered by a Cabinet Secretariat, is an important auxiliary of the police. Internal security duties are the responsibility of the Department of National Security Intelligence, which operates under the authority of the President's Secretariat.

The Armed Police Reserve (36,000 personnel) is primarily a riot control force, but may support the Army if the need arises. Another paramilitary outfit, the Bangladesh Rifles, is a border defence force similar to India's Assam Rifles.

Bangladesh Police Directorate, Dacca (404003)

Department of National Security Intelligence, Dacca (402203)

Department of Anti-Corruption, Dacca (244868)

\section{OPERATIONS}

The problems of Bangladesh are mainly of a social nature; the country is very poor, overpopulated and politically unstable. In spite of these conditions, crime figures are not particularly high and a limited drop in the number of offences known to the police can be observed from the following official statistics. It should be noted that the figures for the 1972-5 period reflect the agitation of the civil war that brought about Bangladesh's independence and the difficult times that followed the end of the hostilities.

$\begin{array}{cccc}\text { year } & \begin{array}{c}\text { total no. } \\ \text { crimes }\end{array} & \text { murders } & \text { riots } \\ 1972 & 55,119 & 5357 & 11,094 \\ 1973 & 74,275 & 1494 & 7140 \\ 1974 & 85,648 & 2703 & 8316 \\ 1975 & 74,291 & 1590 & 7891 \\ 1976 & 61,909 & 1935 & 8460 \\ 1977 & 62,152 & 1770 & 8211 \\ 1978 & 64,808 & 1623 & 9675 \\ 1979 & 62,986 & 1802 & 8422 \\ 1980 & 58,155 & 1891 & 7910\end{array}$

